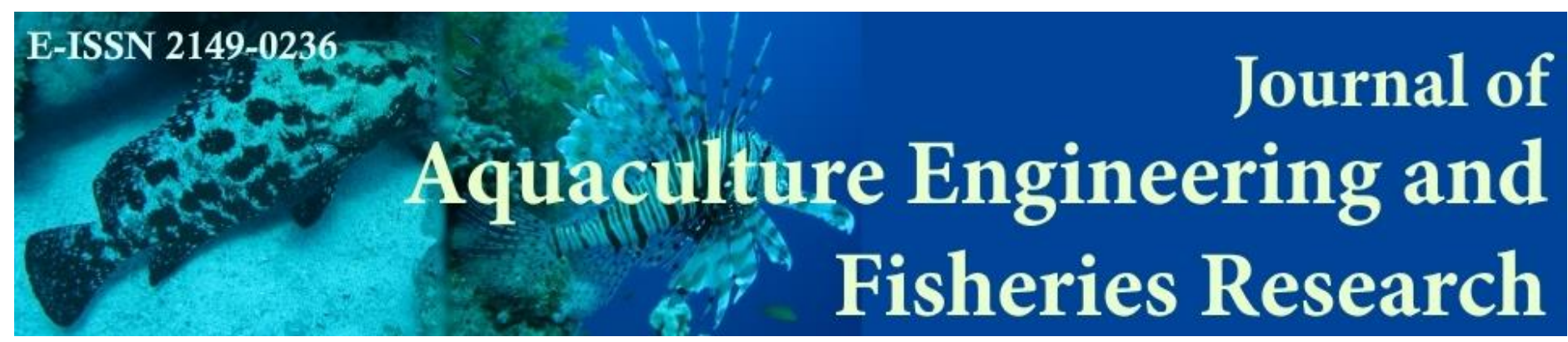

FULL PAPER

TAM MAKALE

\title{
MOTILITY EVALUATION AND CRYOPRESERVATION OF FISH SPERM EXPOSED BY WATER-BORNE AND FOOD-BORNE BORON
}

\author{
Burak Evren İnanan ${ }^{1} \stackrel{\text { id }}{\text {, Fevzi }}$ Yılmaz ${ }^{2}$ id
}

Cite this article as:

İnanan B.E., Y1lmaz, F. (2018). Motility Evaluation and Cryopreservation of Fish Sperm Exposed By Water-Borne and Food-Borne Boron. Journal of Aquaculture Engineering and Fisheries Reaserch, 4(1), 12-19. DOI: 10.3153/JAEFR18002

1 Aksaray University, Eskil Vocational School, Department of Veterinary Science, Aksaray, Turkey

2 Muğla Sitkı Koçman University, Faculty of Science, Department of Biology, Muğla, Turkey

Submitted: 31.05 .2017

Accepted: 23.11.2017

Published online: 21.12 .2017

Correspondence:

Burak Evren INANAN

E-mail:

burakinanan@aksaray.edu.tr

Journal of Aquaculture Engineering and Fisheries Research

E-ISSN 2149-0236

4(1), 12-19 (2018)

DOI: 10.3153/JAEFR18002

ScientificWebJournals (SWJ)

(C)2015-2018

\begin{abstract}
Boron (B) is required for organisms as an essential nutrient, whereas could be toxic in definite doses. In this study, for the first time, the effects of water-borne and food-borne B on fish sperm motility were initially determined and these sperm samples were cryopreserved in liquid nitrogen aiming to reveal how the quality of these samples are affected by cryopreservation. 12 mature male goldfish (Carassius auratus) individuals for each treatment performed in triplicate for 45 days were used in the study. Fish were fed with diets containing $1 \mathrm{mg}, 5 \mathrm{mg}$ and $10 \mathrm{mg}$ of B per kg feed for foodborne experiments. In waterborne experiments, fish were kept in aquariums containing $1 \mathrm{mg} / \mathrm{L}, 10 \mathrm{mg} / \mathrm{L}$ and $20 \mathrm{mg} / \mathrm{L}$ of $\mathrm{B}$. In both fresh and cryopreserved samples, the motility durations (s) and percentages of the sperm samples, vitality of spermatozoa (\%) were determined. In the fresh samples, percentages of sperm motility and viability in the both B treatments decreased compared to the control, while increasing B concentration. After cryopreservation, the sperm samples in $5 \mathrm{mg}$ of B per $\mathrm{kg}$ feed treatment has shown higher duration of sperm motility. Therefore, it is shown that feed-borne B could improve sperm resistance to cold shock.
\end{abstract}

Keywords: Boron, Carassius auratus, Sperm motility, Sperm vitality, Cryopreservation 


\section{Introduction}

Boron (B) is a micro-mineral and a trace element, with properties between that of a metal and a nonmetal which is present in the environment (sedimentary rocks, soils, coal, seawater, etc.) in different forms such as borates, boric acid, boric oxide and salts (Samman et al., 1998; Bustos-Obregon and Olivares, 2012; Kabu and Akosman, 2013). Commercially important deposits of boron-containing minerals are found in the United States, Turkey, South America, Russia, and China (Woods, 1994). There has been a long-standing usage of B. For instance, it was used by the ancient Egyptians in mummification and medicine. Nowadays, B minerals are used manufacture of glass fibers, ceramics, cleaning materials (detergents), bleaches, alloys, fire retardants, fertilizers, wood preservatives, cosmetics antifreeze, brake fluids and motor oil, particularly in the United States, China and Europe (Scialli et al., 2010).

A limit of $0.3 \mathrm{mg} \mathrm{B} / \mathrm{L}$ could be acceptable for drinking water (Simonnot et al., 2000). Generally, surface and ground waters are below this limit but in the regions of borate mines and some industrial discharges B levels were determined around $7 \mathrm{mg} / \mathrm{L}$. (Okay et al.,1985; Recepoglu and Beker, 1991). On the other hand, the average concentration of B in seawater is approximately $5 \mathrm{mg} / \mathrm{L}$ (Song and Huang, 1987). Boron as borate compounds or boric acid is an essential element for plant growth, an essential nutrient in some animals and humans at defined concentrations (Blevins and Lukaszewski, 1994; Devirian and Volpe, 2003; Nielson, 2008). The toxicological studies in mammals have shown that the toxic effects of B on central nervous system, cardiovascular system, and axial skeleton. But the most sensitive endpoints originated from B toxicity are observed on the reproductive system where effects are detected at much lower dose levels (Ku et al., 1993).

Cryopreservation as an assisted reproduction method is the use of very low temperatures (typically in liquid nitrogen) to preserve structurally intact living cells like spermatozoa (Pegg, 2007). Moreover, cryopreservation of sperm offers many advantages such as improving artificial reproduction, facilitating genetic manipulation (Chao and Liao, 2001). Conceptually, the procedure of cryopreservation could be divided into two main processes; the freezing and the thawing. These processes have potential to damage sperm cells especially associated with loss of integrity of cell membrane and oxidative stress (Suquet et al., 1998). B has a part in cell membrane functions, anti-oxidative defense systems, structure of cell transporter, and cations metabolism, which are very critical for sperm quality (Goldbach et al., 2001; Park et al., 2004; Alavi and Cosson, 2006; Kabu and Akosman, 2013). Taking in consideration B functions in organisms, it is motivated to study on the effects of B on sperm quality of fish, and cryopreservation of this sperm. Thus, this study aims to investigate the effects of water-borne and foodborne $\mathrm{B}$ at different concentrations on fish sperm quality, vitality of spermatozoa and mainly resistance to cryopreservation of sperm obtained from fish exposed by B.

\section{Materials and Methods}

Two hundred and fifty-two (1.5-2 years old, $7.8 \pm 1.2 \mathrm{~g}, 18.6$ $\pm 3.8 \mathrm{~cm})$ male which were never stripped before and sexually mature sixty-three female goldfish (Carassius auratus) purchased from commercial dealer were used for experiments. Each treatment was done in three replicates using three aquariums of which each contains 45 liters of water with 12 male fish. The fish were kept 45 days in total in aquariums, last two weeks 3 females were put into each aquarium for matching and thereby making easier abdominal stripping of male fish. The experiments carried out the Aquarium Laboratory of Biology Department at Muğla S. K. University using with tap water $(\mathrm{pH} 7.97 \pm 0.4$; dissolved oxygen (DO) $>8 \mathrm{mg} / \mathrm{L}$, and boron (B) concentration $<0.001 \mathrm{mg} / \mathrm{L}$ ) at $16 \pm 0.5^{\circ} \mathrm{C}$ on a 10 -h dark and 14 -h light (10D:14L) photoperiod. After putting the female fish, temperature of the aquarium water gradually increased to 22 $\pm 0.5^{\circ} \mathrm{C}$ on $8 \mathrm{D}: 16 \mathrm{~L}$ photoperiod during the last two weeks of the experiments. Thus, any hormone injections were avoided when obtaining sperm samples. DO and $\mathrm{pH}$ were measured with a portable HQ40D multimeter (Hach Lange, Germany) and a micro pH meter (WTW pH 320, Germany) respectively while $\mathrm{B}$ concentrations were determined by an ICP-MS procedure (Agilent 7700x, Germany) described as in Genç et al. (2015).

Besides the control groups which fed with B free pellets and in aquariums with tap water, the experimental design was composed of two main groups; food-borne and water-borne groups. All fish were fed daily with $2 \mathrm{~mm}$ feed pellets of around $2 \%$ of total fish wet weight. The water-borne B treatments were obtained adding 1,10 and $20 \mathrm{mg} / \mathrm{L}$ of B concentrations to the aquariums. However, the pellets contained 1, 5 and $10 \mathrm{mg} / \mathrm{kg}$ of B concentrations were used in the foodborne B treatments. Each aquarium was supplied with tap or relevant B levels containing fresh water with $25 \%$ changes of it every two days and aeration to maintain enough DO. Eventually, together with the control group, there were seven treatments in the experimental design. In the foodborne B treatments, cornmeal oil (10 $\mathrm{ml} / \mathrm{kg}$ feed) was used to bind B to the fish feed (Ardo et al., 2008). The prepared feed was maintained at room temperature. B concentrations were adjusted using with boric acid $\left(\mathrm{H}_{3} \mathrm{BO}_{3}\right.$, Sigma-Aldrich, Germany) in all experiments. The condition factor (K) 


\title{
Journal of Aquaculture Engineering and Fisheries Research, 4(1), 12-19 (2018)
}

\author{
Journal abbreviation: J Aquacult Eng Fish Res
}

of the experimental fish was estimated from the relationship: $\mathrm{K}=\left(\mathrm{W} / \mathrm{L}^{3}\right)^{*} 100$ (Bagenal and Tesch, 1978).

The fish fasted for $24 \mathrm{~h}$ before the start of the experiments were anaesthetized in $50 \mu \mathrm{1} / \mathrm{L}$ of clove oil (Öğretmen et al., 2014). Sperm samples were collected by manual abdominal stripping by the help of pipette while avoiding any contamination from water, urine or faeces.

Sperm samples of 3 males were selected from each aquarium and then totally 9 samples were pooled as representative of each treatment. The motility characteristics of the pooled samples of spermatozoa (expressed as durations and percentages) were estimated by mixing an activation solution containing $45 \mathrm{mM} \mathrm{NaCl}, 5 \mathrm{mM} \mathrm{KCl}$, and $30 \mathrm{mM}$ Tris $-\mathrm{HCl}$, pH8.2 (Horváth et al., 2003) under a light microscope at $400 \times$ magnification at a semen:activation solution ratio of 1:100 on microscope slides.

Eosin-nigrosin staining for vitality of spermatozoa (\%) was performed according to the concept of using eosin to mark dead cells, which take up eosin, and nigrosin as a black background (Blom, 1950). $10 \mu \mathrm{l}$ of semen was mixed in a glass tube with firstly $50 \mu 1$ of $0.5 \%$ eosin and then $100 \mu \mathrm{L}$ of $10 \%$ nigrosin which dissolved in $0.9 \%$ sodium chloride in distilled water (modified from Björndahl et al., 2003).

Following the stripping and pooling of the semen samples, they were placed in 12-ml glass test tubes on ice immediately under aerobic conditions. The pooled semen samples were mixed in a ratio of 1:9 (v/v) with an extender composed of modified Kurokura solution $(62 \mathrm{mMol} \mathrm{NaCl}, 134 \mathrm{mMol}$ $\mathrm{KCl}, 2 \mathrm{mMol} \mathrm{CaCl}, 1 \mathrm{mMol} \mathrm{MgCl}_{2}$, and $2 \mathrm{mMol} \mathrm{NaHCO}_{3}$, $\mathrm{pH}$ 8.2, $378 \mathrm{mOsm}), 10 \%$ DMSO, and 10\% egg yolk (Magyary et al., 1996). After dilution, the samples were drawn into $0.25 \mathrm{ml}$ straws (IMV, France) and sealed with polyvinyl alcohol. Next, the straws were placed on a rack $2.5 \mathrm{~cm}$ above a liquid nitrogen surface for $10 \mathrm{~min}$ and then plunged directly into the liquid nitrogen. At least seven straws per a sperm sample were frozen. After a week of storage in liquid nitrogen, the samples were thawed in a $30^{\circ} \mathrm{C}$ water bath for $10 \mathrm{~s}$. the activation solution described above was also used to evaluate for the motility characteristics of cryopreserved samples. A $1 \mu 1$ drop of sample was placed on a microscope slide, $100 \mu \mathrm{l}$ of the activation solution was added, and then the sperm suspensions were thoroughly mixed for $2 \mathrm{~s}$. The percentages of motile sperms and motility durations were immediately recorded with a CCD video camera (with a Nikon DS-U3 controller, Japan) mounted on a phase-contrast microscope (Nikon Ci-S, Japan) at 400× magnification at room temperature until the spermatozoa trajectories become tight concentric circles (Rurangwa et $a l ., 2004)$. The obtained video records were scanned to determine the percentages of progressive motility $(\%)$ and the durations of progressive motility (s). The sperm motility percentages were estimated as the percentage of cells that exhibited progressive forward movement (Horváth et al., 2003), and the durations of motility were determined as the times until forward movement stopped and circular movement began. The percentages of sperm motility were assessed using an arbitrary scale with $10 \%$ interval increments in which non-motility was recorded as $0 \%$ (modified from Borges et al., 2005). An aliquot of each straw were determined, and the average motility characteristics were then calculated.

The results are shown as the means \pm the standard deviation (SD). Non-parametric Mann-Whitney U tests followed by Kruskall-Wallis test were used. Prior to analysis, the original percentage data were transformed by arcsine transformation. $\mathrm{P}$ values less than .05 were taken to indicate significant differences the treatments in terms of motility characteristics.

\section{Results and Discussion}

As an essential nutrient, B is a necessary dietary for not just to metabolisms of bacteria, fungi, plants, animals and but also to humans (Hunt, 1994; Goldbach et al., 2001). B, like other microelements, could be toxic in definite doses, depending on how organisms taken in (Blevins and Lukaszewski, 1994). The effects have been confirmed in many experiments and studies on organ systems as well as reproduction system. In some mammalian species such as rats, mice, and dogs, the negative effects of oral administration of boric acid and borax were reported on the testis and following on sperm and spermiation (Scialli et al., 2010). It has been clearly indicated the nutritional essentiality of boron for normal reproduction and maturation in frog (Xenopus laevis) (Fort et al., 1999). Also, the requirement of B during embryonic development zebrafish (Danio rerio) has been reported clearly. A supplementation of B concentration of $45 \mu \mathrm{mol} / \mathrm{L}$ of $\mathrm{B}$ supplementation to the water improved hatching rates of fertilized eggs, comparing to 0.1 $\mu \mathrm{mol} / \mathrm{L}$ of $\mathrm{B}$ concentration in water (Rowe and Eckhert, 1999). Moreover, male reproductive studies especially about their semen characteristics of B-exposed workers, who work in boric acid production plant, B processing plants or B mine in China and Turkey, has revealed the scientific awareness of B effects on reproduction (Duydu et al., 2012; Başaran et al., 2012; Scialli et al., 2010 ).

Regarding to $\mathrm{K}$ values, there were no significant differences among the groups $(\mathrm{P}>0.05)$ at both the beginning which is 
not represented and the end of the experiment (Figure 1). The average $\mathrm{K}$ values in the control were found $3.94 \pm 0.79$. $\mathrm{K}$ values were calculated in water-borne treatments as $4.01 \pm 1.20,3.91 \pm 1.12$ and $3.42 \pm 0.65$, respectively in 1,10 and $20 \mathrm{mg} / \mathrm{L}$ of $\mathrm{B}$ groups while $3.49 \pm 0.98,4.91 \pm 1.92$ and $4.19 \pm 1.36$ were found for food-borne treatments 1,5 and 10 $\mathrm{mg} / \mathrm{kg}$ of $\mathrm{B}$, respectively.

The percentages of sperm vitality obtained from samples at the end of the experiment were represented in Figure 2. Sperm vitality was found in the control as $97.2 \pm 0.6 \%$. In contrast to $\mathrm{K}$ values, there were significant differences among the percentages of sperm vitality $(\mathrm{P} \leq 0.05)$. Increasing with the $\mathrm{B}$ concentration, a decrease in sperm vitality was observed. In water-borne groups, sperm vitality values were calculated $92.5 \pm 0.4,88.0 \pm 0.8$ and $84.1 \pm 0.2 \%$ as 1,10 and $20 \mathrm{mg} / \mathrm{L}$ of $\mathrm{B}$ groups, respectively. In food-borne groups (1, 5 and $10 \mathrm{mg} / \mathrm{kg}$ of $\mathrm{B}$ groups), the average values of sperm vitality were found $91.8 \pm 2.3,83.0 \pm 0.5$ and $81.0 \pm 1.6 \%$, respectively.

Motility percentages and durations of both fresh pooled and post-thaw sperm samples treated by boron (B) with water- borne $(1,10$ and $20 \mathrm{mg} / \mathrm{L}$ of $\mathrm{B}$ in water) and food-borne (1, 5 and $10 \mathrm{mg} / \mathrm{kg}$ of B in pellets) were shown in Table 1 , comparing with the control. The average motility percentages and durations of the fresh sperm sample in the control were $91.7 \pm 2.9 \%$ and $58.3 \pm 2.9 \mathrm{~s}$, respectively. Percentages of progressive motility were recorded as $66.7 \pm 5.8$ and $58.3 \pm 2.9 \%$ in $20 \mathrm{mg} / \mathrm{L} \mathrm{B}$ and $10 \mathrm{mg} / \mathrm{kg}$ B groups, respectively. In the treatments, motility percentages were decreased while B concentrations were increased for both water-borne and food-borne groups. This pattern was not observed in motility durations. The highest average of progressive motility percentage was found in $1 \mathrm{mg} / \mathrm{L}$ of B group as $62.7 \pm 1.2 \%$. After the application of cryopreservation, the average motility percentage and duration were recorded $48.3 \pm 2.9 \%$ and $33.0 \pm 2.6 \mathrm{~s}$ in the control. No significant difference was found among the water-borne groups in terms of post-thaw progressive motility values. Among the cryopreserved samples obtained from the food-borne groups, the highest motility percentage and duration were in the 5 $\mathrm{mg} / \mathrm{kg}$ of B as $53.3 \pm 5.8 \%$ and $40.3 \pm 2.5 \mathrm{~s}$. Especially the average of progressive motility duration determined in this treatment was higher than the value in the control $(\mathrm{P} \leq 0.05)$.

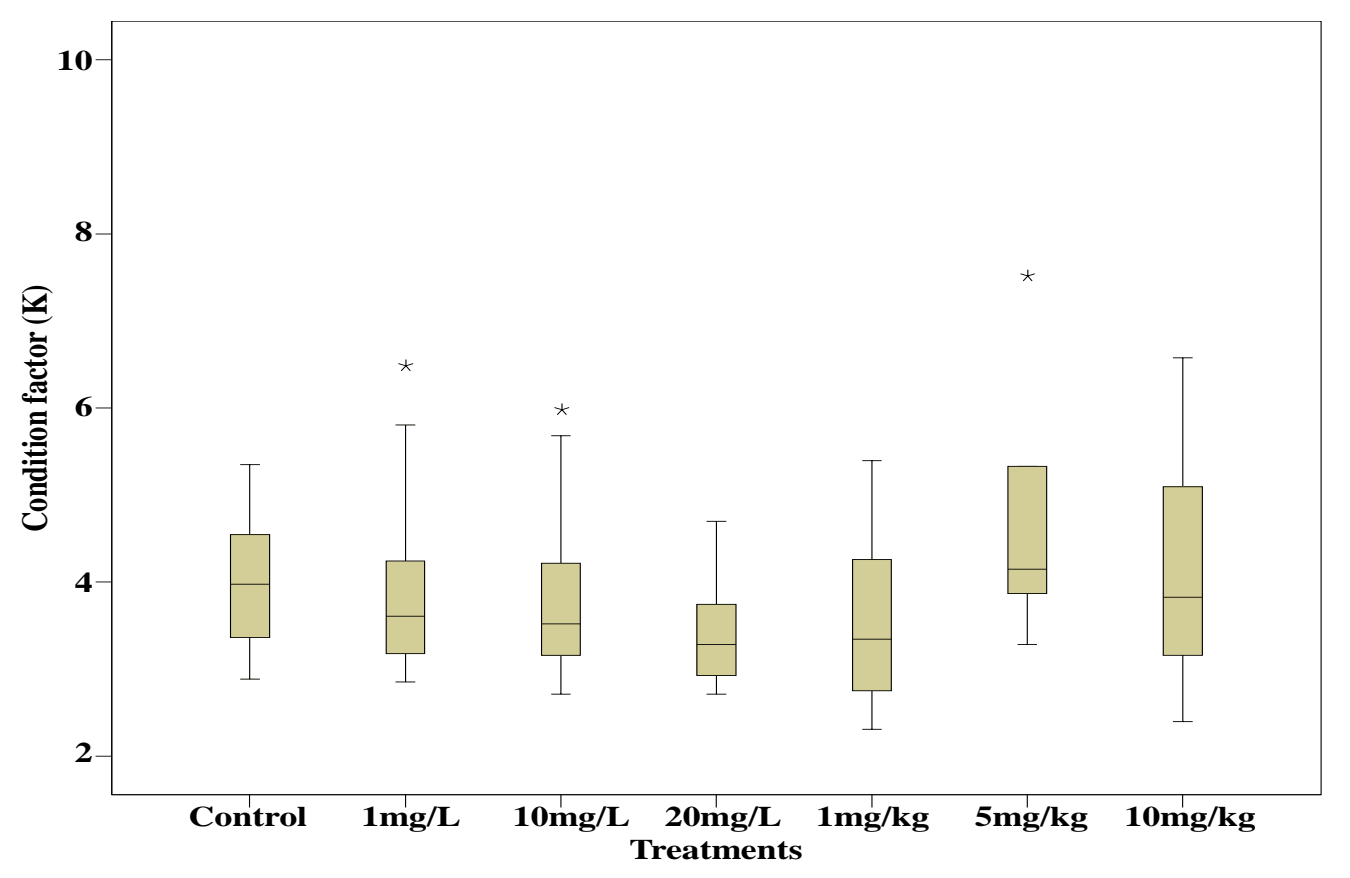

Figure 1. The condition factor $(\mathrm{K})$ of the male fish in the control and the treatments (water-borne; $1,10 \mathrm{and} 20 \mathrm{mg} / \mathrm{L} \mathrm{of} \mathrm{B}$ in water and food-borne; 1,5 and $10 \mathrm{mg} / \mathrm{kg}$ of B in pellets) at the end of the experiment. No significant differences were found among the groups ( $\mathrm{n}=36$ for each group, $\mathrm{P}>0.05)$. The box plot represents the median and $25 / 75$ th percentile, whereas asterisks indicate outliers. 


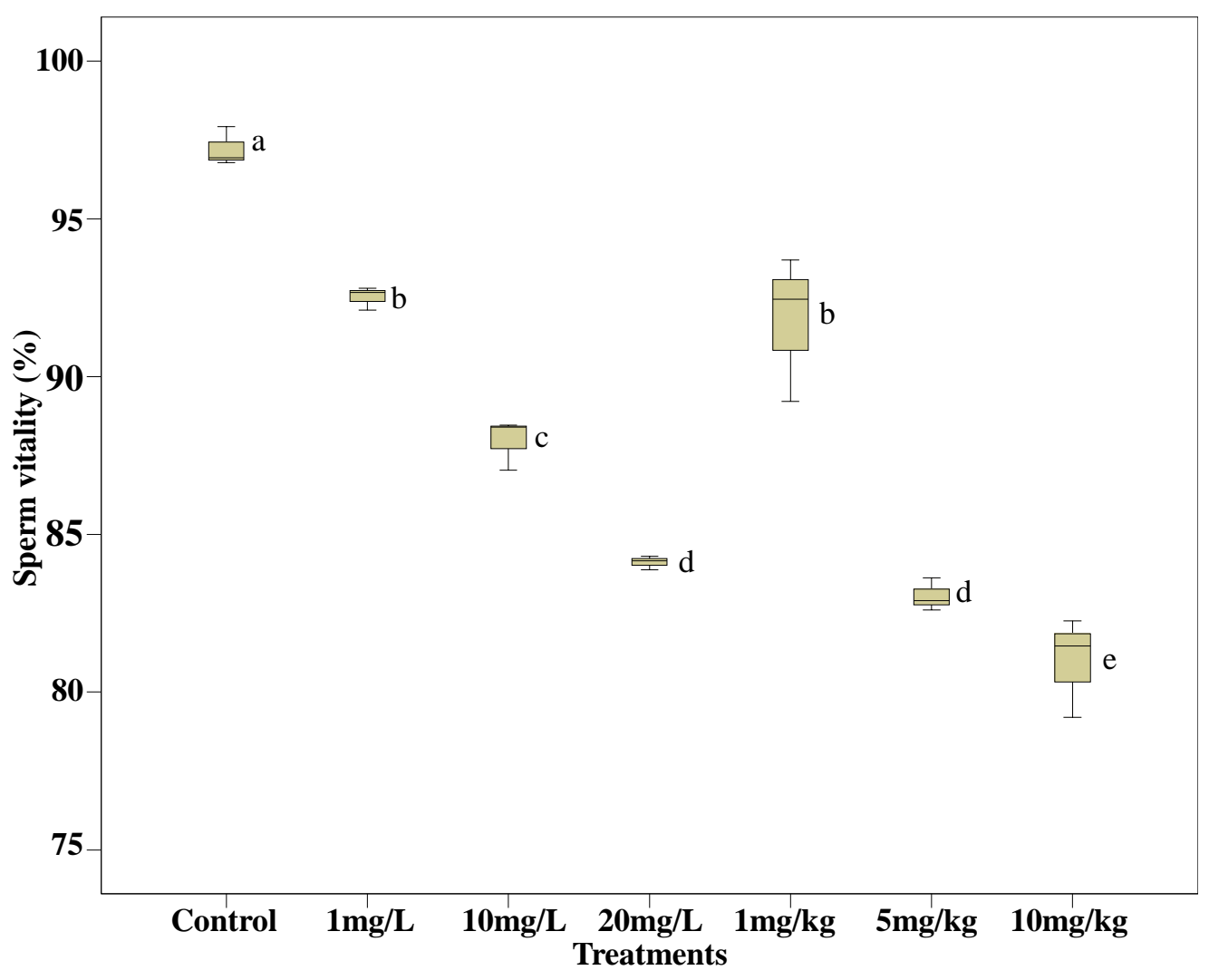

Figure 2. The percentages of sperm vitality (\%) of the male fish in the control and the treatments (waterborne; 1,10 and $20 \mathrm{mg} / \mathrm{L}$ of B in water and food-borne; 1,5 and $10 \mathrm{mg} / \mathrm{kg}$ of B in pellets) at the end of the experiment. The same superscript letters did not differ from each other $(n=36$ for each group, $\mathrm{P} \leq 0.05$ ). The box plot represents the median and 25/75th percentile.

Table 1. Motility percentages (\%) and durations (s) of fresh pooled and post-thaw sperm samples of goldfish (C. auratus) treated by boron (B) with water-borne $(1,10$ and $20 \mathrm{mg} / \mathrm{L}$ of B in water) and food-borne $(1,5$ and $10 \mathrm{mg} / \mathrm{kg}$ of $B$ in pellets).

Fresh Pooled Sperm Samples $\quad$ Post-thaw Sperm Samples

\begin{tabular}{ccccc}
\hline Treatments & $\begin{array}{c}\text { Progressive motility } \\
(\%)\end{array}$ & $\begin{array}{c}\text { Duration of progres- } \\
\text { sive motility }(\mathbf{s})\end{array}$ & $\begin{array}{c}\text { Progressive motility } \\
(\%)\end{array}$ & $\begin{array}{c}\text { Duration of progres- } \\
\text { sive motility }(\boldsymbol{s})\end{array}$ \\
\hline Control & $91.7 \pm 2.9^{\mathrm{a}}$ & $58.3 \pm 2.9^{\mathrm{a}}$ & $48.3 \pm 2.9^{\mathrm{a}}$ & $33.0 \pm 2.6^{\mathrm{a}}$ \\
\hline $1 \mathrm{mg} / \mathrm{L}$ & $83.3 \pm 2.9^{\mathrm{ad}}$ & $62.7 \pm 1.2^{\mathrm{b}}$ & $25.0 \pm 5.0^{\mathrm{b}}$ & $18.7 \pm 1.5^{\mathrm{b}}$ \\
\hline $10 \mathrm{mg} / \mathrm{L}$ & $86.7 \pm 2.9^{\mathrm{a}}$ & $54.7 \pm 1.5^{\mathrm{a}}$ & $36.7 \pm 5.8^{\mathrm{b}}$ & $34.0 \pm 6.6^{\mathrm{ad}}$ \\
\hline $20 \mathrm{mg} / \mathrm{L}$ & $66.7 \pm 5.8^{\mathrm{bc}}$ & $44.3 \pm 2.5^{\mathrm{c}}$ & $31.7 \pm 2.9^{\mathrm{b}}$ & $23.7 \pm 2.1^{\mathrm{c}}$ \\
\hline $1 \mathrm{mg} / \mathrm{kg}$ & $85.0 \pm 5.0^{\mathrm{ae}}$ & $51.3 \pm 1.2^{\mathrm{d}}$ & $48.3 \pm 2.9^{\mathrm{a}}$ & $32.3 \pm 2.1^{\mathrm{a}}$ \\
\hline $5 \mathrm{mg} / \mathrm{kg}$ & $73.3 \pm 5.8^{\mathrm{bde}}$ & $56.0 \pm 1.0^{\mathrm{a}}$ & $53.3 \pm 5.8^{\mathrm{a}}$ & $40.3 \pm 2.5^{\mathrm{d}}$ \\
\hline $10 \mathrm{mg} / \mathrm{kg}$ & $58.3 \pm 2.9^{\mathrm{c}}$ & $49.3 \pm 1.2^{\mathrm{d}}$ & $33.3 \pm 2.9^{\mathrm{b}}$ & $33.3 \pm 1.2^{\mathrm{a}}$ \\
\hline
\end{tabular}




\section{Journal of Aquaculture Engineering and Fisheries Research, 4(1), 12-19 (2018)}

Journal abbreviation: J Aquacult Eng Fish Res

It has been shown that B supplemented diets improve testis weight in Frog (Fort et al., 1999). In general, percentages of sperm vitality significantly decreased with increasing B levels $(\mathrm{P} \leq 0.05)$. The lowest percentage of sperm vitality was observed in $10 \mathrm{mg} / \mathrm{kg}$ of $\mathrm{B}$ in food-borne treatments. The negative effects of $B$ levels on progressive motility percentages were recorded in fresh sperm samples $(\mathrm{P} \leq 0.05)$. Like sperm vitality, the lowest percentage of sperm motility was found in $10 \mathrm{mg} / \mathrm{kg}$ of B treatment. Similarly, a decrease in motility percentages was also reported in frog and some mammalian species (Fort et al., 1999; Scialli et al., 2010). In humans, no adverse effects of B on male reproduction can be demonstrated (Liu et al., 2005; Duydu et al., 2012). However, it was emphasized that the possibility of a bias in the selection of subjects for semen evaluation may have been emerged (Scialli et al., 2010). Also, B exposures of selected subjects could be under the conditions of human handling and use (Bolt et al., 2012).

Additionally, results of our study showed that durations of progressive motility were also decreased with the exception of the highest motility durations in $1 \mathrm{mg} / \mathrm{kg}$ of B food-borne group, even higher than the control slightly but significantly $(\mathrm{P} \leq 0.05)$. In cryopreserved sperm samples, while percentages of progressive motility were close, duration of progressive motility recorded in $5 \mathrm{mg} / \mathrm{kg}$ of B food-borne group higher than those values in control significantly. B functions, particularly at cell level, could induce this positive effect on motility duration. Cellular membrane functions of B and its role in anti-oxidative defense systems have been suggested clearly in plants (Goldbach et al., 2001; Cakmak and Römheld, 1997). Whereas B functions in plants are well documented, its functions in animals have been started to study lately. For instance, it was shown that a boron transporter, called $\mathrm{NaBC} 1$, as mammalian homologue of the AtBOR1 borate transporter, occurring ubiquitously in animal cell membranes (Park et al., 2004), This $\mathrm{NaBC1}$ transporter conducts $\mathrm{Na}^{+}$which one of the major cations in semen (Alavi and Cosson, 2006) and in the absence of borate. Also, $\mathrm{B}$ has effects on energy metabolism and $\mathrm{Ca}^{++}$and $\mathrm{Mg}^{++}$metabolisms which are substantial for sperm motility (Alavi and Cosson, 2006; Kabu and Akosman, 2013).

\section{Conclusion}

In essence, results of our study showed that the motility characteristics of sperm of $C$. auratus were inhibited by exposing to water-borne and food-borne B. On the other hand, after cryopreservation of the samples, the motility characteristics in the $5 \mathrm{mg} / \mathrm{kg}$ of $\mathrm{B}$ from the food-borne groups were improved, comparing with the control group signifi- cantly. Regarding the observable effects of B on sperm quality, using of B in studies on reproductive biology and fish as a model species are to encourage for further studies. Our study suggest the need for further studies of in vitro effect of B on quality of sperm, particularly adding B to cryomedium at low doses. Furthermore, analysis of oxidative stress of semen samples treated by B and also determining the accumulation of B in gonadal tissue and semen are needed to be studied.

\section{Acknowledgements}

This research was supported by Grant No. 12/51 from the Muğla Sitkı Koçman University Research Fund. The authors would like to thank Assoc. Prof. Dr. Murat Yabanl1 from Muğla Sitkı Koçman University for his help to the research.

\section{References}

Alavi, S.M., Cosson, J. (2006). Sperm Motility in Fishes. (II) Effects of Ions and Osmolality: a Review. Cell Biology International, 30(1), 1-14.

Ardó, L., Yin, G., Xu, P., Váradi, L., Szigeti, G., Jeney, Z., Jeney, G. (2008). Chinese Herbs (Astragalus membranaceus and Lonicera japonica) and Boron Enhance the Non-Specific Immune Response of Nile tilapia (Oreochromis niloticus) and Resistance Against Aeromonas hydrophila. Aquaculture, 275, 26-33.

Bagenal, T.B., Tesch, F.W. (1978). Age and growth. In: T.B. Bagenal (Ed.), Methods for Assessment of Fish Production in Fresh Waters (p. 101-136). Oxford: Blackwell Scientific Publications. ISBN 0632001259

Başaran, N., Duydu, Y., Bolt, H.M. (2012). Reproductive Toxicity in Boron Exposed Workers in Bandirma. Turkey Journal of Trace Elements in Medicine and Biology, 26, 165-167.

Björndahl, L., Söderlund, I., Kvist, U. (2003). Evaluation of the One-Step Eosin-Nigrosin Staining Technique for Human Sperm Vitality Assessment. Human Reproduction, 18(4), 813-816.

Blevins, D.G., Lukaszewski, K.M. (1994). Proposed Physiologic Functions of Boron in Plants Pertinent to Animal and Human Metabolism. Environmental Health Perspectives, 102(7), 31-33. 


\section{Journal of Aquaculture Engineering and Fisheries Research, 4(1), 12-19 (2018)}

Journal abbreviation: J Aquacult Eng Fish Res

Blom, E. (1950). A One-Minute Live-Dead Sperm Stain by means of Eosin- Nigrosin. Fertility and Sterility, 1, 176-177.

Bolt, H.M., Başaran, N., Duydu, Y. (2012). Human environmental and occupational exposures to boric acid: reconciliation with experimental reproductive toxicity data. Journal of Toxicology and Environmental Health, Part A, 75(8-10), 508-514.

Borges, A., Siqueira, S.R., Jurinitz, D.F., Zanini, R., Amaral, F., Grillo, M.L., Oberst, E.R., Wassermann, G.F. (2005). Biochemical Composition of Seminal Plasma and Annual Variations in Semen Characteristics of Jundia Rhamdia quelen (Quoy and Gaimard, Pimelodidae). Fish Physiology and Biochemistry, 31, 45-53.

Bustos-Obregon, E., Olivares, C. (2012). Boron as Testicular Toxicant in Mice (Mus domesticus). International Journal of Morphology, 30(3), 1106-1114.

Cakmak, I., Römheld, V. (1997). Boron Deficiency-induced Impairments of Cellular Functions in Plants. Plant and Soil, 193, 71-83.

Chao, N., Liao, I.C. (2001). Cryopreservation of Finfish and Shellfish Gametes and Embryos. Aquaculture, 197, 161-189.

Devirian, T.A., Volpe, S.L. (2003). The Physiological Effects of Dietary Boron. Critical Reviews in Food Science and Nutrition, 43, 219-231.

Duydu, Y., Başaran, N., Üstündağ A., Aydın, S., Ündeğer, Ü., Ataman, O.Y., Aydos, K., Düker, Y., Ickstadt, K., Waltrup, B.S., Golka, K., Bolt, H.M. (2012). Assessment of DNA Integrity (COMET assay) in Sperm Cells of Boron-exposed Workers. Archives of Toxicology, $86,27-35$.

Fort, D.J., Stover, E.L., Strong, P.L., Murray, F.J. (1999). Effect of Boron Deprivation on Reproductive Parameters in Xenopus laevis. The Journal of Trace Elements in Experimental Medicine, 12, 187-204.

Genç, T.O., İnanan, B.E., Yabanlı, M., Yılmaz, F. (2015). The Aggregation of Boron on the Tissues of Gold Fish (Carassius auratus Linnaeus, 1758). Turkish Journal of Agriculture - Food Science and Technology, 3(6), 498-503.
Goldbach, H.E., Yu, Q., Wingender, R., Schulz, M., Wimmer, M., Findeklee, P., Baluska, F. (2001). Rapid Response Reactions of Roots to Boron Deprivation. Journal of Plant Nutrition and Soil Science, 164, 173-181.

Horváth, A., Miskolczi, E., Urbanyi, B. (2003). Cryopreservation of Common Carp Sperm. Aquatic Living Resources, 16, 457-460.

Hunt, C.D. (1994). The Biochemical Effects of Physiologic Amounts of Dietary Boron in Animal Nutrition Models. Environmental Health Perspectives, 102(7), 3542.

Kabu, M., Akosman, M.S. (2013). Biological Effects of Boron. Reviews of Environmental Contamination and Toxicology, 225, 57-75.

Ku, W.W., Chapin, R.E., Wine, R.N., Gladen, B.C. (1993). Testicular toxicity of boric acid (BA): relationship of dose to lesion development and recovery in the F344 rat. Reproductive Toxicology, 7, 305-319.

Liu, P., Wang, C., Hu, J., Xun, L., Robbins, W.A., Wu, G. (2005). Preliminary study on pregnancy outcome of spouses of boron workers. Chinese Journal of Public Health, 21(5), 567-568.

Magyary, I., Urbanyi, B., Horvath, L. (1996). Cryopreservation of Common Carp (Cyprinus carpio L.) Sperm II. Optimal Conditions for Fertilization. Journal of Applied Ichthyology, 12, 117-119.

Nielson, F.H. (2008). Is Boron Nutritionally Relevant? Nutrition Reviews, 66, 183-191.

Okay, O., Güçlü, H., Soner, E., Balkas, T. (1985). Boron Pollution in the Simav River, Turkey and Various Method of Boron Removal. Water Research, 19(7), 857-862.

Öğretmen, F., Gölbaşi, S., İnanan, B.E., Kizak, V., Kayim, M. (2014). Use of Clove Oil and Eugenol to Anesthetize Fingerling Shabut Barbus grypus. North American Journal of Aquaculture, 76(1), 9-13.

Park, M., Li, Q., Shcheynikov, N., Zeng, W.Z., Muallem S. (2004). $\mathrm{NaBC1}$ Is a Ubiquitous Electrogenic $\mathrm{Na}^{+}$-coupled Borate Transporter Essential for Cellular Boron 
Homeostasis and Cell Growth and Proliferation. Molecular Cell, 16(3), 331-341.

Pegg, D.E. (2007). Principles of Cryopreservation. Methods in Molecular Biology, 368, 39-57.

Recepoğlu, O., Beker, U. (1991). A Preliminary Study of Boron Removal From Kizildere/Turkey Geothermal Waste Water. Geothermics, 20(1/2), 83-89.

Rowe, R.I., Eckhert, C.D. (1999). Boron Is Required For Zebrafish Embryogenesis. Journal of Experimental Biology 202, 1649-1654.

Rurangwa, E., Kime, D.E., Ollevier, F., Nash, J.P. (2004). The Measurement of Sperm Motility and Factors Affecting Sperm Quality in Cultured Fish. Aquaculture, 234, 1-28.

Samman, S., Naghii, M.R., Lyons Wall, P.M. \& Verus, A.P. (1998). The Nutritional and Metabolic Effects of Boron in Humans and Animals. Biological Trace Element Research, 66, 227-235.

Scialli, A.R., Bonde J.P., Brüske-Hohlfeld, I., Culver, B.D., Li, Y., Sullivan, F.M. (2010). An Overview of Male
Reproductive Studies of Boron With an Emphasis on Studies of Highly Exposed Chinese Workers. Reproductive Toxicology, 29, 10-24.

Simonnot, M., Castel, C., Nicolaiè, M., Rosin, C., Sardin, M., Jauffret, H. (2000). Boron Removal From Drınkıng Water With a Boron Selective Resin: Is The Treatment Really Selective? Water Research, 34(1), 109-116.

Song, D., Huang, L. (1987). The Design of a $200 \mathrm{~m}^{3} / \mathrm{d}$ Deboronation System and its Field trials on Xisha Islands. Water Treatment, 2, 141-147.

Strum, L.M.G. (1978). Aspects of the biology of Scomberomorus maculatus (Mitchill) in Trinidad. Journal of Fish Biology, 13, 155-172.

Suquet, M., Dreanno, C., Petton, B., Normant, Y., Omnes, M.H., Billard, R. (1998). Long Term Effects of the Cryopreservation of Turbot (Psetta maxima) Spermatozoa. Aquatic Living Resources, 11, 45-48.

Woods, W.G. (1994). An Introduction to Boron: History, Sources, Uses and Chemistry. Environmental Health Perspectives, 102(7), 5-11. 